\title{
Dos viajeras latinoamericanas en la Europa del siglo XIX. Identidades nacionales y de género en perspectiva comparada: Maipina de la Barra (1834-1904) y Nisia Floresta (1810-1885)
}

\section{Two Latin American women travelers in Europe in the nineteenth century. National identities and gender in comparative perspective: Maipina de la Barra (1834-1904) and Nisia Floresta (1810-1885)}

\author{
Stella Maris Scatena Franco ${ }^{1}$ \\ Carla Ulloa Inostroza ${ }^{2}$
}

\section{Resumo}

Este artigo compara os relatos de viagem das autoras brasileira e chilena, Nísia Floresta (1810-1885) e Maipina de la Barra (1834-1904). Alguns aspectos biográficos são apresentados e a relativa marginalidade dessas mulheres é discutida. Na sequência, debate o tema da "falsa modéstia" nos textos das autoras, como uma estratégia de integração em seus respectivos campos culturais. Finalmente, analisa as visões das viajantes sobre a Europa, sugerindo que suas perspectivas se atrelam às interpretações canônicas então vigentes em suas regiões de origem, como a dicotomia civilização/barbárie, no Chile, e o ideário unificador do Estado brasileiro, que exaltou a natureza do país.

Palavras-chave: Viagem; gênero; Brasil; Chile; século XIX

\begin{abstract}
This article compares the travel writings of the Brazilian and Chilean authors, Nísia Floresta (1810-1885) and Maipina de la Barra (1834-1904). Some biographical aspects are presented and the relative marginality of these women are discussed. Following, the article debates the subject of "false modesty" in the writings of these authors, considering it as a strategy of integration in their cultural fields. Finally, analyzes their views about Europe, suggesting that their perspectives were linked to the canonical interpretations then prevailing in their regions of origin, as the dichotomy civilization/barbarism, in Chile, and the unifying ideology of the Brazilian state, which exalted the nature of the country.
\end{abstract}

Keywords: Travel; gender; Brazil; Chile; nineteenth century

Artigo recebido em: 31/08/2014

Artigo aprovado para publicação em: 25/10/2014

\footnotetext{
${ }^{1}$ Professora de História da América Independente - Departamento de História - Universidade de São Paulo (USP). E-mail: stellafv@usp.br

${ }^{2}$ Editora do website Mujeres Viajeras: http://historiasmujeresviajeras.blogspot.com

Doutoranda em Estudos Latino-Americanos na Universidade Nacional Autônoma do México (UNAM).

E-mail: carla.ulloa.i@gmail.com
}

\section{GANPHLAC}

Revista Eletrônica da ANPHLAC, ISSN 1679-1061, No. 17, p. 304-324, jul./dez. 2014. http://revista.anphlac.org.br/ 
Nísia Floresta y Maipina de la Barra fueron mujeres letradas decimonónicas, ambas sudamericanas, siendo la primera brasileña y la segunda chilena. Tuvieron en común el hecho de realizar viajes a Europa y producir relatos, en los cuales cuentan sus experiencias sobre el llamado "mundo civilizado". Tales narraciones viajeras nos invitan a la comparación y nos plantean preguntas: ¿Fueron "mujeres excepcionales" porque tenían la audacia de viajar solas? ¿Cómo conciliar esta imagen excepcional con el retrato que pintaban de sí mismas atado a la domesticidad y a la imagen tradicional de la mujer? ¿Sus visiones de Europa reproducían estereotipos comunes a los textos de escritores latinoamericanos (hombres)? ¿Cuáles son las semejanzas y las singularidades en sus interpretaciones sobre lo "otro"?

Si la comparación fue pensada como un medio capaz de contribuir a superar las limitantes de una historia estrictamente nacional, más recientemente, en "tiempos de globalización", viene siendo objeto de críticas, justamente por limitarse a marcos nacionales. Aún así, ella ofrece un camino fértil de análisis (Prado, 2005). Las diferentes percepciones de las escritoras-viajeras aquí abordadas están ancladas en las interpretaciones canónicas vigentes en sus países de origen. La identidad nacional se impone como un elemento importante para el análisis y abre posibilidades de entendimiento sobre las diferencias entre países que tienen historias comunes. Si en las particularidades tienden a aparecer las visiones distintas del "otro", en el discurso de género la cuestión de la domesticidad (Stuven 2007), funciona como un elemento unificador de las trayectorias de Maipina de la Barra y Nísia Floresta.

Para explorar las semejanzas, escogemos tratar el discurso de la "falsa modestia" de las autoras. Con respecto a las diferencias, identificamos características peculiares que llaman la atención en las formas de comprender lo "otro", europeo, y el "yo", latinoamericano (más específicamente, lo chileno y lo brasileño). Estos aspectos son abordados aquí, después de la presentación de las trayectorias de ambas autoras.

\section{Autoras de los márgenes}

Nísia Floresta nació en 1810, en Río Grande del Norte, fue hija de un abogado portugués y de una mujer luso-brasileña y su vida fue un gran viaje. Falleció en 1885 en

\section{GANPHLAC}

Revista Eletrônica da ANPHLAC, ISSN 1679-1061, N. 17, p. 304-324, jul./dez. 2014. http://revista.anphlac.org.br/ 
Francia. Entre su nacimiento y su viaje inicial a Europa, en 1849, ya había vivido en diferentes partes de Brasil: en Río Grande del Norte, en Pernambuco, en Puerto Alegre y en Río de Janeiro. En la primera localidad, se casó a los 13 años, por conveniencia, pero dejó al marido. Poco tiempo después, en Pernambuco, se volvió a casar con un joven estudiante de derecho, con quien tuvo una hija y un hijo. Enfrentó la viudez precozmente. ${ }^{3}$ Todavía muy joven, realizó actividades educativas e intelectuales. En el inicio de la década de 1830 publicó artículos en la prensa de Pernambuco, como el periódico Espelho das Brasileiras, y publicó un libro que le traería notoriedad, una "traducción libre" de Vindication of Rights of Woman, de la feminista inglesa Mary Wollstonecraft, titulado por Nísia como Direito das mulheres e injustiça dos homens. ${ }^{4}$

En Río de Janeiro, fundó en 1838, el Colegio Augusto, volcándose a la educación femenina (dicho colegio fue anónimamente criticado en la prensa). Publicó obras de carácter doctrinario -como Conselhos à minha filha, de 1842; Daciz ou A jovem completa; y Fany ou O modelo das donzelas, de 1847- en las cuales destacaba el papel de la maternidad y la educación de los hijos.

En 1849 inició sus viajes por tierras extranjeras. Se embarcó a París con sus dos hijos, permaneciendo hasta 1852. Asistió a conferencias pronunciadas por Auguste Comte, en su "Curso de Historia General de la Humanidad", enseñadas en el Palais Cardinal. En agosto de 1851, partió a Portugal y luego retornó a Brasil. En Río de Janeiro, publicó en 1853, el Opúsculo Humanitário, que contiene artículos sobre la mujer y la emancipación femenina en diferentes sociedades históricas, de la antigüedad hasta el siglo XIX. En este libro defiende que los progresos de una civilización dependen de la acción de la mujer en la "moralidad de los pueblos".

En 1855 su madre murió en Río de Janeiro y poco después Nísia se embarcó de nuevo para Francia, acompañada únicamente por su hija, esta vez para quedarse más tiempo. Al vivir en París, se acercó a Auguste Comte, que se convirtió en su amigo. Desde París se fue a Alemania en 1856, por un mes. Cerca de dos años más tarde, entre

\footnotetext{
${ }^{3}$ Hay muchas biografias sobre Nísia Floresta. Um estúdio más completo y sistemático está en: Duarte, Constância Lima. Nísia Floresta: vida e obra. Natal: Editora da UFRN, 1995.

${ }^{4} \mathrm{Al}$ respecto ver el interesante ensayo: Pallares-Burke, Maria Lúcia. "A Mary Wollstonecraft que o Brasil conheceu, ou a travessura literária de Nísia Floresta”. In: Nísia Floresta, o Carapuceiro e outros ensaios de tradução cultural. São Paulo: Hucitec, 1996.
}

\section{CANPHLAC}

Revista Eletrônica da ANPHLAC, ISSN 1679-1061, No. 17, p. 304-324, jul./dez. 2014. http://revista.anphlac.org.br/ 
1858 y 1861, hizo un largo viaje a Italia y Grecia. Los viajes a Alemania e Italia y Grecia originaron sus relatos, que utilizamos como fuentes primarias de este artículo.

Los últimos años de su vida estuvieron marcados por sus viajes. Al salir de Italia se instaló de nuevo en París y permaneció en la ciudad hasta 1872, que dejó a causa de la Comuna de París. Teniendo en cuenta los llamados de la familia, regresó a Río de Janeiro, después de haber pasado previamente por Inglaterra y Portugal. Su hija, que tenía 42 años, permaneció en Lisboa.

El año 1875 marcó el regreso definitivo de Nísia Floresta a Europa. Después de volver a Inglaterra y Portugal, regresó a Francia. En 1878 se instaló en Rouen, donde vivió hasta el último de sus días.

No se puede afirmar categóricamente las razones que motivaron la realización de tantos viajes. Nísia usó justificaciones subjetivas. Afirmó querer relajar su espíritu de momentos de sufrimiento, generalmente relacionados a los aniversarios de muerte de su madre y su esposo. Tal vez fue un argumento necesario para el momento: estando los dos muertos, ella no tenía la obligación, como hija y esposa, de cuidar de sus familiares. Mostrando que lamentaba la situación, expuso también su disponibilidad para viajar, una vez que no era responsable de las tareas "naturales" de su sexo. Ella no escribía de forma explícita en sus relatos que los viajes estaban fuertemente motivados por el interés de ampliar el conocimiento y el acceso a un universo cultural más rico.

Hay dudas sobre las condiciones económicas de Nísia Floresta. Mujer de muchos viajes, no dejó clara la fuente de sus posesiones. Es posible que el dinero se haya adquirido de herencia familiar, que no debe haber sido mucho, porque a pesar de haber vivido con un poco de holgura, menciona en varios pasajes de sus relatos los ahorros realizados durante sus viajes.

De acuerdo con algunas perspectivas, Nísia Floresta murió en Francia como una desconocida. Sin embargo, en el siglo XX fue transformada en figura ejemplar, "pionera" del movimiento feminista brasileño. Por regla general, las biografías existentes reproducen los hechos narrados por la autora en sus textos autobiográficos, que, paradójicamente, han contribuido a que muchos aspectos de su vida continúen sin

\section{GANPHLAC}

Revista Eletrônica da ANPHLAC, ISSN 1679-1061, Nº. 17, p. 304-324, jul./dez. 2014. http://revista.anphlac.org.br/ 
claridad. ${ }^{5}$ La falta de información sobre la biografía no parece ser una exclusividad de esta autora, sino más bien una situación que se produce generalmente con las mujeres que ensayaban alguna proyección en el mundo de las letras latinoamericanas del siglo XIX. Consideremos, por ejemplo, el caso de Maipina Copacabana de la Barra Lira, viajera chilena que nació en el año 1834, en París, y murió en Buenos Aires en el año 1904.

Maipina de la Barra fue hija de un reconocido diplomático, académico y político chileno y una ciudadana francesa. Durante su juventud practicó el canto, fue compositora y maestra de piano. En su adultez, con posterioridad a su primer viaje a Europa (1873-1874), ofreció conciertos de piano y pronunció conferencias a favor de la educación de la mujer en Cataluña, en varias ciudades de Chile y en Buenos Aires. Fue autora de traducciones al español del francés e italiano de textos escolares y espiritistas. Fue practicante del hipnotismo y del librepensamiento masónico, iniciada en una logia bonaerense. $^{6}$

Maipina de la Barra no fue una viajera regular, salvo su traslado desde Francia a Santiago de Chile con la edad de cuatro años. Recién en el año 1873, una vez viuda, con treinta y nueve años de edad (al igual que Nísia Floresta), realizó su primer viaje a Europa en compañía de su hija Eva Cobo, de dieciséis años. En ese viaje trasatlántico realizado sobre barcos a vapor y trenes ambas mujeres recorrieron el sur de Chile, atravesando el estrecho de Magallanes y visitando brevemente Buenos Aires, Montevideo y Río de Janeiro. Una vez cruzado el océano Atlántico llegaron a Europa para visitar Burdeos, Marsella, Génova, Turín y Paris. Finalmente se establecieron nueve meses en la capital de Francia.

En el año 1877, tres años después de haber regresado de Europa, Maipina de la Barra decidió emigrar a Argentina para establecerse en Buenos Aires. Parte su segundo viaje completamente sola y encima de una mula, con el objetivo de atravesar la cordillera de los Andes con destino a Buenos Aires. Sola se estableció en esa ciudad en

\footnotetext{
${ }^{5}$ Para un análisis de las "coincidencias" entre las biografias y textos de natureza autobiográfica de Nísia Floresta véase Franco, Stella Maris Scatena. Peregrinas de outrora: viajantes latino-americanas no século XIX. Florianópolis: Editora Mulheres: São Francisco do Sul: Edunisc, 2008, capítulo 1.

${ }^{6}$ Para una revisión general de su obra véase Ulloa, Carla. Crítica social y gestión cultural de una viajera sudamericana: Maipina de la Barra (1834-1904). Tesis para optar al grado de Magíster en Estudios Latinoamericanos, Universidad de Chile, 2012.
}

\section{GANPHLAC}

Revista Eletrônica da ANPHLAC, ISSN 1679-1061, No. 17, p. 304-324, jul./dez. 2014. http://revista.anphlac.org.br/ 
1877 (aunque después volvió a viajar a Europa y a Chile intermitentemente) y escribió el libro "Mis impresiones y mis vicisitudes en mi viaje a Europa pasando por el Estrecho de Magallanes y en mi escursión [sic] a Buenos Aires pasando por la cordillera de los Andes" (Publicado por Pisqueras Cuspinera y Ca. Editores en Buenos Aires en el año 1878 y recientemente reeditado por la Editorial Cuarto Propio en Chile). Ambos viajes, según indica la autora en su libro, se produjeron por una inspiración de Jesús y la Virgen en la una iglesia de Valparaíso. Según relata la autora su físico resentido y un ánimo decaído le habían provocado una "triste situación" que solo se alivió al entender que sus deseos de viaje tenían una inspiración divina. A pesar de que sus contemporáneos le decían a la viajera que Europa era un continente de "países herejes" y "sin religión" Maipina de la Barra partió con su hija, buscando conocimientos y belleza artística.

Otro motivo del viaje era conocer las costumbres y gustos "adelantados" de Europa, para que la hija de la escritora fuera educada en la "civilización" del viejo continente. Este viaje fue emprendido sin más ahorros que los obtenidos de la venta de todos los artículos y bienes que poseía Maipina de la Barra. La viajera explica:

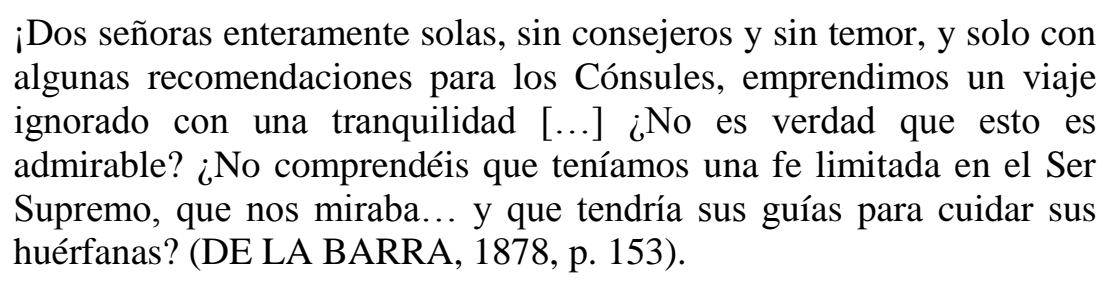

Lo cierto es que en el norte de Italia vivía la madre de Maipina de la Barra y en Francia permanecían aún las amistades de su padre, quienes brindaron a las viajeras alojamiento, contactos y distracciones.

Luego de algunas escalas por el sur de Chile y Argentina Maipina de la Barra y su hija llegaron a Río de Janeiro el 23 de mayo de 1873 (habían partido el día 6 de mayo en Valparaíso) mientras la fiebre amarilla azotaba la ciudad. En Río de Janeiro quedaron maravilladas de la belleza del paisaje, en palabras de Maipina de la Barra "no se sabe dónde dirigir la vista, porque en todas partes hay maravillas que contemplar" (DE LA BARRA, 1878, p. 40), principalmente atractiva para las viajeras resultó el Corcovado y el jardín botánico. En los alrededores de la ciudad visitaron una hacienda de café donde

\section{GANPHLAC}

Revista Eletrônica da ANPHLAC, ISSN 1679-1061, No. 17, p. 304-324, jul./dez. 2014. http://revista.anphlac.org.br/ 
Maipina de la Barra pudo conocer a una esclava llamada Hortensia y conversar con ella, concluyendo que la esclavitud era una injusticia abominable.

El relato de los viajes de Maipina de la Barra por Europa se concentra en las minuciosas descripciones de los espacios que las mujeres tenían ahí; privilegios que no existían en América. Gran parte del libro está dedicado a presentar los "progresos" que brinda a Europa la mujer educada y trabajadora, capaz de llevar adelante una profesión y la maternidad fundamentada en la educación formal. Según la viajera para la época que describe (1873-1874);

Las naciones europeas comprenden hace ya mucho tiempo que no hay progreso, que no hay regeneración posible, sin el concurso poderoso de la mujer, cuya influencia abraza la vida entera del hombre (DE LA BARRA, 1878, p. 162).

Estos reclamos contra las diferencias de género son fundamentados por la autora en que

en los tiempos primitivos, la mujer fue considerada como un ser inferior al hombre, creado tan solo para su servicio absoluto, y yacía en la mayor abyección [...] En la nueva era, merced a la sublime doctrina de Jesús, la mujer ha sido, con la mayor justicia, considerada digna compañera del hombre (DE LA BARRA, 1878, p. 165).

El feminismo de Maipina de la Barra es argumentado desde un punto religioso y civilizador (ideológicamente enlazado con el positivismo y la dicotomía civilizaciónbarbarie propuesta por Juan Faustino Sarmiento). La propuesta del libro consiste en presentar a Europa como un espacio de civilización avanzada y "superior" donde la mujer ocupa un estatus más justo e igualitario al del hombre (como compañera) y oponerlo a la realidad chilena de la autora donde la mujer no goza de igualdad (como subordinada).

Para la época Maipina de la Barra no fue una autora reconocida pero tampoco fue del todo ignorada. Frente a los círculos de poder chilenos la época podría decirse que gozaba de cierta "cercanía", por ejemplo fue prima del intelectual Eduardo de la Barra y gracias a que su padre fue intendente de Santiago, conoció al importante político e historiador Benjamín Vicuña Mackenna. La prensa de la época dedicó notas a sus presentaciones espiritistas y musicales, y también pequeñas reseñas de su libro. La masonería argentina le rindió un gran homenaje a su muerte. Sin embargo, Maipina de la Barra es prácticamente desconocida en Chile, su obra nunca ha sido editada en su país

\section{GANPHLAC}

Revista Eletrônica da ANPHLAC, ISSN 1679-1061, No. 17, p. 304-324, jul./dez. 2014. http://revista.anphlac.org.br/ 
(hasta el 2013) ni tampoco ha sido homenajeada como una de las primeras escritoras feministas chilenas.

Es posible evidenciar algunas semejanzas relevantes en las trayectorias de las autoras. Ambas se dedicaron a la educación femenina. Además, viajaron con recursos relativamente limitados y se emprendieron sus periplos cuando eran viudas, siendo acompañadas por sus hijas. Ellas sintieron la necesidad de justificar sus viajes usando argumentos que pretendían afirmar sus condiciones "femeninas", pasivas y autocompasivas (el "llamado de Dios" por Maipina; el lamento por la muerte de su esposo y su madre, por Nísia). En esta gama de temas comunes la condición de género funciona como elemento que aparentemente limita las actuaciones de las mujeres. Pero a pesar de estas supuestas "barreras", ellas encontraron espacios y discursos útiles a sus estrategias: se publicaron sus obras e viajaron. Además, en ambos casos, las viajeras parecen estar motivadas por un deseo de acceso más amplio a la cultura, lo que puede ser interpretado como un interés de ampliación en sus esferas de actuación, más allá de los roles convencionales asignados al sexo.

\section{Falsa modestia: una retórica obligatoria}

En Brasil, Nísia Floresta ha sido considerada como una de las primeras feministas del país. Su actuación como profesora, viajera y escritora en el siglo XIX, la convierte en ícono de mujer emancipada. Sin embargo, viendo sus propios textos, tenemos a primera vista una impresión diferente que no se condice con el personaje símbolo de la liberación de la mujer brasileña.

En los relatos de viajes y en otros textos de autoría de Floresta, se nota un discurso que valora algunos roles tradicionales asignados a las mujeres. Situaciones vividas en sus viajes son narradas con el fin de tratar de dar ejemplos de "buena" y "mala" conducta femenina. Hizo, por ejemplo, acérrimas críticas a las parisinas burguesas que dejaron a sus hijos con nodrizas y renunciaron a la "tarea sagrada" de la

\section{GANPHLAC}

Revista Eletrônica da ANPHLAC, ISSN 1679-1061, No. 17, p. 304-324, jul./dez. 2014. http://revista.anphlac.org.br/ 
maternidad. Según Nísia Floresta la madre tenía la obligación de ser "siempre buena, siempre complaciente y dedicada hasta la abnegación, que ofrece, en la práctica todos los días, a sus hijos y nietos, el ejemplo de todas las virtudes de la mujer cristiana" (FLORESTA, 1997, p. 83). Los intereses frívolos de la vida mundana deben superarse en aras de la educación y el celo por la familia de los niños, y la mujer debe ser simple y modesta. En este punto, las mujeres francesas son consideradas por Nisía Floresta como el opuesto de las alemanas. Las primeras cambiaban de placer a cada momento, mientras que las otras eran amables, modestas y no necesitaban las frases ingeniosas (FLORESTA, 1998 a, p. 127-128). La caridad se considera una práctica femenina por excelencia, por eso menciona las frecuentes visitas altruistas. Sin embargo, esto debe hacerse en silencio, con modestia, para no obtener la veneración de los demás. En pocas palabras, la mujer no debe ser expuesta públicamente.

Tales argumentos entran en contradicción con la actividad primordial de Nísia Floresta, que era la escritura. No es difícil de entender, por lo tanto, que pidiese ciertas "licencias" para el espacio público, para entrar en un territorio en el cual no era adecuado explorar ciertos temas considerados "asuntos serios" que deben ser abordados por los "más calificados", es decir, por los hombres. Las demostraciones de falsa modestia y expresiones de auto negación son bastante comunes en sus escritos. Están presentes en las declaraciones que no tenía intención de publicar sus obras y en la manifestación de la falta de interés en la controversia que provoca cuando el tema se refirió a cuestiones políticas. Sobre este último punto, podemos decir que el Vaticano y el Papa eran su tema preferido, pero después de discutir las actitudes con respecto al poder religioso y temporal, afirmaba no poder dar un veredicto final, dejando esa tarea a las personas más "competentes" de lo que, presumiblemente, era una mujer:

La pluma de una mujer no debe parar aquí, porque no es para ella desarrollar un asunto tan serio. Sólo esbozaré la impresión que tuve cuando entré por primera vez en el Vaticano, hablé al Papa e escuché sus palabras. (FLORESTA, 1998 b, p. 121).

Nísia Floresta esquivó los temas cerrados como los relacionados con las posiciones políticas. Afirmó que al viajar, ella no estaba cumpliendo ningún "fín científico" sólo la sanación de un gran dolor. Ante los lectores, se propone como una

\section{GANPHLAC}

Revista Eletrônica da ANPHLAC, ISSN 1679-1061, No. 17, p. 304-324, jul./dez. 2014. http://revista.anphlac.org.br/ 
humilde admiradora, al igual que alguien que describe sus experiencias de viaje, sin tratar de sacar conclusiones. En sus palabras, sus resultados eran "flores marchitas de un espíritu pobre" (FLORESTA, 1998 b, p. 359).

De acuerdo a algunos análisis, esta práctica fue recurrente en la literatura producida por mujeres, siendo estereotipos internalizados en la conciencia femenina, ligado a los orígenes de esta experiencia de la subordinación y a la relación frágil con el poder (RUSSOTO, 1994, p. 809). El concepto de la falsa modestia es muy bien tratado por Bonnie Frederick (1998) para el caso de las escritoras argentinas del mismo periodo que abordamos aquí.

A pesar de las afirmaciones tan categóricas de Nísia Floresta en relación a la preservación de los papeles tradicionales de las mujeres, no se debe, desde nuestro punto de vista, interpretar su actuación como meramente pasiva. Es posible pensar la falsa modestia como una estrategia discursiva preventiva, adoptada para disfrazar una acción que, justamente, contrariaba la convención más ampliamente aceptada, cual es que las mujeres eran "ángeles del hogar" que debían permanecer alejadas de la esfera pública. Pedir licencia, declarar falta de pretensiones como escritoras, aún cuando sus trabajos tienen tópicos políticos, puede ser interpretado como una forma de buscarse un espacio abierto en el campo intelectual, mayoritariamente ocupado por los hombres. Esto tanto para el caso brasileño como el chileno.

También Maipina de la Barra escribió "Mis impresiones y mis vicisitudes" en un doble juego entre afirmación de una postura personal y la disminución de su propia opinión. Este tipo de escritura obedece igualmente a la estrategia de la falsa modestia, mediante la cual pudo acceder a la palabra pública sin perder de vista su objetivo político. Maipina de la Barra utilizó este mecanismo en su libro donde trata de aminorar su obra señalando: "no pretendo ser escritora [...] Sedme, mis amables lectoras, indulgentes para leer esta obrita" (DE LA BARRA, 1878, p. 11). Al respecto Graciela Batticuore apunta que la pedantería y ridiculez eran formas de descalificación usuales para desautorizar a las escritoras desde el siglo XVII en Europa, y habían sido las formas usadas para socavar el honor de la escritora y de su familia (2005, p. 14). Por ello las autoras latinoamericanas de fines del siglo XIX debían realizar negociaciones

\section{GANPHLAC}

Revista Eletrônica da ANPHLAC, ISSN 1679-1061, No. 17, p. 304-324, jul./dez. 2014. http://revista.anphlac.org.br/ 
con el campo cultural de su época, en un contexto de restricción del espacio social para la mujer.

Así la falsa modestia se utilizó como un mecanismo discursivo fundamental para que las mujeres escritoras del diecinueve pudieran acceder al discurso público desde la candidez del "bello sexo" y su humildad. Al respecto Nara Araújo apuntó las posibles causas:

Esta dualidad ambivalente es quizás el resultado de una tensión, no siempre antagónica, entre el respecto a un deber ser y la búsqueda de voz propia, que encuentra el reconocimiento y la legitimación mediante la escritura [...] coexisten la autodevaluación y la autoproclamación $[\ldots]$

La retórica de la minusvalía es propia a los prólogos escritos por mujeres a sus libros, en el siglo XIX, y la autoproclamación asume de manera explícita la postura competitiva en el terreno de lo público, respetando a la institución patriarcal (ARAÚJO, 2008, p. 1016).

Efectivamente cuando Maipina de la Barra señaló en la dedicatoria del libro que no pretendía ser escritora estaba diciendo que no quería ser considerada escritora profesional, como sus contemporáneas argentinas Juana Manso o Juana Manuela Gorriti. Pero también estaba queriendo evitar igualarse a figuras masculinas reconocidas y autorizadas para escribir.

El texto de Maipina de la Barra está intervenido por una autocensura evidenciando un cuidado extremo de lo que se dice. Todos los argumentos que la autora utiliza están secundados por "dios" o por el bien supremo de la nación; son inclinaciones a la "regeneración de la humanidad", son argumentos permitidos y validados. Norma Alloatti (2009) analiza este aspecto de la autoría de la escritora como un documental de la época. Según su investigación De la Barra dedicó su obra a otras mujeres porque ellas entenderán mejor lo que se está relatando, cuidándose con especial atención la frontera del mundo femenino, si se quiere, del mundo doméstico.

Nísia Floresta y Maipina de la Barra, accedieron al mismo discurso y recurrieron a la misma estrategia, indicando una aparente modestia de sus relatos de viaje. Consideramos que estas coincidencias obedecen a la búsqueda de aceptación de sus lectores y lectoras.

\section{Visiones sobre Europa y los países de origen: encuentros y desencuentros}

\section{GANPHLAC}

Revista Eletrônica da ANPHLAC, ISSN 1679-1061, Nº 17, p. 304-324, jul./dez. 2014. http://revista.anphlac.org.br/ 
Nísia Floresta pasó gran parte de su vida en viajes por Europa, por medio de los cuales se conectó con la producción letrada del viejo continente. En un primer momento podríamos pensar que ella tenía una admiración ciega por el continente, supuestamente entendido como mucho "superior" en el desenvolvimiento del progreso en relación a los recién independizados países de América Latina, y particularmente Brasil. Esta lectura no se confirma cuando se exploran las ideas que se desarrollaron en sus relatos de viajes.

Nísia no hace un análisis sistemático con el fin de darse cuenta de los "lugares" ocupados por Europa y América. En vez de eso, desarrolla una interpretación perspicaz, que tiende a elevar la posición de su país de origen, y que resignifica las imágenes originalmente creadas para denigrar a Brasil (en Europa). La mejor forma de comprender las relativizaciones que realizó en el discurso canónico de oposición entre "desarrollo europeo" y "atraso americano" es observar sus reflexiones sobre la naturaleza y la civilización en sus escritos de viaje.

La naturaleza es uno de los aspectos primordiales en sus relatos, mas sabemos que este no es un hecho aislado. Por el contrario, se inscribe en una tradición de producción de narrativa, profusamente leídas por europeos y americanos. Dentro de los viajeros europeos hacia a América, Alexander von Humboldt desenvolvió un papel seminal en las interpretaciones que asociaban a América con naturaleza, como parte fundamental del proceso de "reimaginación" del Nuevo Mundo por los europeos, en el contexto de las independencias políticas de las colonias americanas. América fue representada como "naturaleza primal, [como] espacio atemporal y mundo no organizado en sociedades e economías" (PRATT, 1999, p. 223-224). Humboldt inauguró una nueva manera de describir los viajes científicos: sin abandonar la ciencia, su estilo "tiende a una 'prosa poética', alcanzando el 'sentimento y la fantasia'" (LISBOA, 1995, p. 24). Incluso sin poner un pie en Brasil, el impacto de sus viajes se hizo sentir en el país, haciendo eco también en los relatos de Nísia Floresta, que exagera los superlativos cuando trata la naturaleza de su país.

Algunas metáforas demuestran grandes dimensiones físicas. Ella habla del "continente brasileño"; su "planeta predilecto"; el río Amazonas es el "mayor del

\section{GANPHLAC}

Revista Eletrônica da ANPHLAC, ISSN 1679-1061, No. 17, p. 304-324, jul./dez. 2014. http://revista.anphlac.org.br/ 
mundo" (FLORESTA, 1997, p. 9, 33, 51). Una visión poética de la naturaleza también surge cuando recuerda del Brasil después de viajar dos años por Italia. Ahí registró la salida de Brasil describiendo la Bahía de Guanabara desde el punto de vista de quien estaba en un barco: un manto de vegetación cubría las montañas que "devoraban" Río de Janeiro y Niterói, conforme el barco se distanciaba de la costa. Esta imagen de la "Bahía más bella del mundo" se reflejaba temporalmente en las aguas, hasta desaparecer en el horizonte y conservarse sólo en la memoria (FLORESTA, 1998 b, p. 85). Nísia contrapone las visiones despreciativas de los trópicos, reforzando los trazos positivos de la naturaleza. Al retratar la provincia de Pernambuco, afirmaba que a pesar de localizarse en los trópicos tórridos, se extendía por una planicie, localización que le proporcionaba aire puro. El calor era aminorado por las lluvias, por los innumerables ríos y por las noches frescas. La región es descrita como un verdadero edén: brisas suaves, bosques frondosos, flores, árboles colosales y frutosos, un murmullo melancólico de las olas del mar... (FLORESTA, 1997, p. 21-23).

Como buena viajera, no escapó de las inevitables comparaciones. En ellas, los escenarios naturales eran un tema privilegiado. La grandiosidad natural de Brasil fue confrontada con las dimensiones mínimas de la naturaleza europea: ríos, golfos y la vegetación brasileña son retratados como mayores que las europeas y los frutos brasileños son descritos como más sabrosos. En este sentido leemos una notoria estrategia de afirmación de superioridad de su país frente a la "pobre Europa". En compensación, había en el paisaje europeo algo que estaba ausente en América: las marcas de la presencia humana. En Europa, el arte y la historia irrumpían en las ruinas y en las construcciones incorporadas en la naturaleza. El exuberante Vesuvio, con su fuerza natural, estaba permeado de historia, con las antiguas ciudades (como Pompeya y Herculano) enterradas bajo las cenizas del volcán. Así en el pasaje europeo arte y naturaleza eran elementos indisociables. Al respecto Maipina de la Barra también notaba la tremenda intervención humana en la naturaleza europea, asunto que la maravillaba ya que el trabajo productivo, y la total ocupación de la tierra en la producción de alimentos y bienes, otorgaba a Europa una superioridad de carácter, una determinación para el trabajo, que en comparación a Chile, era mayor. Aquí observamos una semejanza y diferencia simultánea en ambas viajeras, lo que es motivo de belleza

\section{GANPHLAC}

Revista Eletrônica da ANPHLAC, ISSN 1679-1061, No. 17, p. 304-324, jul./dez. 2014. http://revista.anphlac.org.br/ 
para Nísia, es motivo de admiración por el proyecto europeo para Maipina. Ambas comparan, pero para la chilena la óptica está determinantemente influida por su apelación a la dicotomía civilización-barbarie. En el cuadro de las comparaciones creadas por la brasileña, ella señala que el dominio humano, el arte, la historia y la civilización son aspectos que corresponden al territorio europeo, la naturaleza virgen, la ausencia de los hitos de la civilización, son rasgos que conforman la imagen construida de Brasil. Si se reproduce una representación de lo exótico, no se puede negar que ha hecho un esfuerzo por rechazar las ideas de algunos viajeros europeos que describían a los brasileños como poco civilizados. Nísia los acusó de falta de información y de generalizaciones. Ella destacó los aspectos positivos de su país, en vez de enfatizar lo primitivo como Maipina de la Barra. Esto era en concepción de Nísia una manera de poner el país en la misma altura de las naciones civilizadas. Pensó así una forma combinatoria y no excluyente: el Brasil "agregaba las magnificencias de la naturaleza y los placeres de una civilización progresiva, que se encontraban en muchas partes de su territorio.” (FLORESTA, 1997, p. 9).

El Brasil tenía una "naturaleza vigorosa” y, aunque joven, tenía también "heroicas tradiciones". Vivía la "aurora de la civilización”, encaminándose en dirección a un "futuro grandioso" (FLORESTA, s/d, p. 132). Nísia reforzó la idea de un país con disponibilidad de riquezas naturales y procuró destacar el camino progresivo de Brasil en la ruta de la civilización. En la naturaleza, su país superaba a Europa; en la civilización, en Europa se miraba. En ninguna instancia proyectó una imagen inferior de Brasil, como era frecuente en los discursos europeos. Maipina de la Barra tampoco proyectó una imagen completamente inferior de Chile, sino como veremos más adelante, comparó a la Europa civilizada (en relación al rol de la mujer ahí) con un Chile incivilizado (donde las mujeres poseían muy pocas garantías y espacios). Notamos aquí una gran coincidencia, de distintas maneras, ambas autoras están recalcando una identidad positiva, que tiene desafíos por delante, haciendo un notorio llamado de atención a sus lectores e interviniendo en el debate por el futuro de América, tal como los reconocidos críticos, filósofos y escritores de sus épocas.

Para Maipina de la Barra Europa representaba la civilización y el ideal que América debían alcanzar. Ella había nacido en París, pero se había educado en Chile,

\section{GANPHLAC}

Revista Eletrônica da ANPHLAC, ISSN 1679-1061, N. 17, p. 304-324, jul./dez. 2014. http://revista.anphlac.org.br/ 
país que durante el siglo XIX vio en Europa su modelo ideal de República, especialmente en Inglaterra y Francia, por lo tanto era obvia esa afirmación. La época en que Maipina de la Barra viajó a Europa fue un momento definitorio para Chile. Desde 1860 y hasta 1890 aproximadamente, se había intensificado la ocupación militar de las tierras del pueblo mapuche. Se estaba llevando a cabo un proyecto de "civilización" del país, tanto en lo que tiene que ver con modernizaciones como en lo educativo y étnico. Ese proceso violento, tanto por la Guerra del Pacífico como por la Pacificación de la Araucanía, se enmarcaba dentro de la lógica que establecía una dicotomía entre "civilización" y "barbarie", bastante aceptada en Chile". Por esto no extraña que Maipina de la Barra haya estado de acuerdo con el proyecto civilizatorio. Sin embargo, buscamos retratar las grandes diferencias que sitúan a la viajera en la contracara de este proyecto. Maipina de la Barra no solo condenó el sometimiento indígena en el sur de Chile (específicamente en la zona de Punta Arenas) sino también la esclavitud en Brasil, y su fascinación con Europa no fue imitativa sino crítica.

La mayor parte de las referencias de De la Barra a Europa como un lugar de “civilización” se encuentran en los pasajes en que ella comparaba las libertades de las mujeres americanas versus las europeas. De todas maneras, Maipina de la Barra no admira "toda" Europa, sino los espacios donde la industria y el orden han avanzado, por eso cuando su viaje por Francia termina y da paso a su travesía por Italia se muestra disconforme señalando:

Desde que pisamos el suelo de Italia (preciso es decirlo, para que cese tanta indolencia de parte de las empresas) en cada estación se sentían malos olores y ya no había fuentes de cristalinas aguas, ni flores, ni mujeres que cuidasen de los viajeros que llegasen enfermos (DE LA BARRA, 1878, p. 89).

\footnotetext{
${ }^{7}$ Durante las décadas de 1830 y 1840 Domingo Faustino Sarmiento, principal portavoz de la idea de civilización en contraposición a la barbarie en el Conosur, vivió en Chile producto de su exilio político. En Chile llegó a ser Ministro de Instrucción Pública, enviado especial del país a Europa y Estados Unidos para investigar los sistemas de enseñanza, fue un connotado escritor en los periódicos más importantes del país y miembro de la Universidad de Chile (Institución fundada el año 1842 por Andrés Bello). Sus ideas tuvieron amplio eco en Chile y en la generación que gobernaría el país a fines del siglo XIX.
}

\section{GANPHLAC}

Revista Eletrônica da ANPHLAC, ISSN 1679-1061, No. 17, p. 304-324, jul./dez. 2014. http://revista.anphlac.org.br/ 
Para Maipina de la Barra Europa significa un lugar con mayores espacios para la mujer. En su paso por Burdeos, Francia, al contemplar la procesión de Corpus-Cristi dirige su atención a las monjas que circulan y señala:

formaban parte de tan solemne fiesta; pero no me causaba tanta extrañeza la rareza de sus trajes, como el verlas discurrir por las calles, pues yo creía que así como en América, debían en Europa estar sujetas a una estricta clausura (DE LA BARRA, 1878, p. 77-78).

Maipina de la Barra articula su libro "Impresiones y Vicisitudes" en torno a una permanente suerte de comparación entre la realidad de las mujeres europeas y las chilenas o americanas. Consideramos que esta forma de presentar el relato a las/os lectoras/es obedece a una estrategia que busca posicionar a Europa como un espacio “civilizado" y "superior" a América, pero a la vez más justo para la mujer. En ese sentido, todo el relato de Maipina de la Barra está atravesado por observaciones sobre las mujeres en la sociedad, en el espacio público, en los ritos sociales. Tal como señala el historiador Manuel Vicuña "en suma la experiencia del viaje ilustrado suministró puntos de comparación que permitieron someter a análisis las falencias y ventajas de la sociedad chilena" (VICUÑA, 2010, p. 93).

\section{Conclusiones: comparaciones}

Las comparaciones no siempre son obvias. Evidenciarlas depende de un esfuerzo de análisis que tenga en consideración el contexto de producción de las obras estudiadas, ya sea para identificar las semejanzas como para destacar las diferencias. En la comparación de los relatos de viajes Nísia Floresta y Maipina de la Barra por Europa, hemos trabajado las visiones críticas sobre nuestra américa. Poniendo lado a lado las apreciaciones de estas escritoras, percibimos la incorporación de representaciones dominantes en sus países de origen, pero también sus aportes e innovaciones en el discurso nacional de Brasil y Chile.

La valorización mucho más explícita de la realidad europea, por parte de Maipina de la Barra, nos remite al proceso histórico chileno, que envuelve al campo cultural del XIX en ese país. No podemos olvidar que Chile el principal asilo para los

\section{GANPHLAC}

Revista Eletrônica da ANPHLAC, ISSN 1679-1061, No. 17, p. 304-324, jul./dez. 2014. http://revista.anphlac.org.br/ 
intelectuales argentinos exiliados en la dictadura de Juan Manuel de Rosas (1829-1852). Dos en especial, Domingo Faustino Sarmiento y Juan Bautista Alberdi, fueron los principales exponentes de una generación que vislumbró en Europa (y también en Estados Unidos, para el caso de Sarmiento), un modelo de civilización que debía inspirar el progreso de las naciones americanas. Situación bastante trabajada por los investigadores de Sarmiento, es la dicotomía entre "civilización y barbarie", presentada en Facundo, que inclusive fue redactado en Chile. En esta dicotomía había considerable dosis de idealización que respaldaba a Europa como centro de la civilización. Esta concepción es central en el examen que Maipina de la Barra hizo de Europa. La experiencia europea, podría ayudar a mejorar la sociabilidad de mujeres y hombres en Chile, elevar el rol de la mujer y propiciar un adelanto social para el país.

No podemos afirmar que en Brasil la situación haya sido totalmente diferente, pero, ¿cómo explicar el hecho de Nísia Floresta no hizo en sus relatos apreciaciones tan positivas de Europa, ni tampoco una fuerte depreciación de su país de origen? Aquí también es preciso atender aspectos coyunturales que marcaron la historia de este país. A diferencia de los países hispánicos de América, en Brasil el régimen predominante fue el monárquico. No se puede menospreciar el hecho de que la Corte se instaló ahí. Los movimientos provinciales contrarios a la extrema centralización de Brasil fueron rechazados con la fuerza estatal. Para completar, la idea de unidad de un país de proporciones continentales estaba ideológicamente sustentada por letrados que orbitaban en la Corte y que vivían del Estado monárquico. El Instituto Histórico y Geográfico Brasileño puede ser citado como uno de los mejores ejemplos en este sentido. Para sustentar la unidad se hacía una extrema valorización de las características nacionales, que buscaban encubrir las diferencias entre las regiones del Brasil. La naturaleza, gigantesca, prolífica, grandiosa, fueron los elementos preferenciales de este programa abarrotado de contenido nacionalista. La apreciación de Nísia Floresta dialoga directamente con esta tradición. Estaba atenta al riesgo de que su interpretación de la naturaleza brasileña reprodujera interpretaciones peyorativas del exotismo y para prevenirse de esto, destaca que el país estaba en el camino de la civilización.

En cuanto a las similitudes, apreciamos que son mas frecuentes cuando se trata de cuestiones de género. En primer lugar, destacamos una analogía existente entre las

\section{GANPHLAC}

Revista Eletrônica da ANPHLAC, ISSN 1679-1061, No. 17, p. 304-324, jul./dez. 2014. http://revista.anphlac.org.br/ 
propias trayectorias de las autoras. Ambas fueron muy poco reconocidas públicamente. Nísia es actualmente considerada como una de las precursoras del feminismo en Brasil, pero esta es una evocación contemporánea de su memoria. No fue sino a partir de la década de 1990 que algunas de sus obras, publicadas originalmente en francés y en italiano, fueron traducidas al portugués. Maipina permanece aun más olvidada en Chile, y su segunda patria; Argentina, lugar donde se integró a una vida intelectual activa (a través de círculos masónicos, de conferencias y la publicación de su libro) y donde permaneció los últimos treinta años de su vida.

Estas escritoras-viajeras insistieron en la falsa modestia. La caridad silenciosa, el altruismo, la disminución de las propias cualidades, son ejemplos de cómo se movilizó esta estrategia retórica. Una vez que la presencia femenina en la esfera pública no era tan aceptada, la movilización de este discurso funcionó como una estrategia para facilitar la inserción de las mujeres. A pesar de haber sido mujeres activas que articularon medios de participación en el ámbito público, ellas permanecieron en los márgenes. No participaron de los cánones literarios de sus respectivos países. Ocuparon, cuando mucho, una posición menor, sin ser reconocidas como referencias importantes en el mundo de las letras nacionales.

Como resultado de este esfuerzo comparativo es posible afirmar que la dimensión de la identidad de género parece cumplir aquí un papel unificador. Floresta y De la Barra no se conocieron pero se aproximaron bastante en las imágenes proyectadas sobre la mujer y sus estrategias de movilización de discursos que tenían como fin un lugar más influyente para la actuación femenina en la sociedad. A pesar de haber pasado por experiencias parecidas como viajeras, de ser oriundas de países que tenían en común la colonización europea no se expresaron por medio de afinidades latinoamericanas. Por el contrario, fueron las identidades nacionales, forjadas por las tradiciones historicas de Brasil y Chile, las que influenciaron en sus formas de concebir la experiencia de la alteridad, lo que contribuyó para enmarcar las diferencias en sus apreciaciones sobre Europa.

\section{GANPHLAC}

Revista Eletrônica da ANPHLAC, ISSN 1679-1061, Nº. 17, p. 304-324, jul./dez. 2014. http://revista.anphlac.org.br/ 


\section{Referencias documentales y bibliográficas}

ALLOATI, Norma. El afán de compartir experiencias: los viajes de Francisca Espínola de Anastay (1850) y de Maipina de la Barra (1878). Ponencia presentada en el Coloquio Montevideana VI “Los viajeros y el Río de la Plata”, Uruguay, junio 2009.

ARAÚJO, Nara. Verdad, poder y saber: escritura de viajes femenina. Revista Estudios Feministas, número 16, Florianópolis, 2008.

BATTICUORE, Graciela. La mujer romántica. Lectoras, autoras y escritores en la Argentina: 1830-1870. Edhasa, Buenos Aires, 2005.

DE LA BARRA, Maipina. Mis impresiones y mis vicisitudes en mi viaje a Europa pasando por el Estrecho de Magallanes y en mi escursión a Buenos Aires pasando por la cordillera de los Andes. Pisqueras Cuspinera y Ca. Editores, Buenos Aires, 1878.

Mis impresiones y mis vicisitudes en mi viaje a Europa pasando por el Estrecho de Magallanes y en mi excursión a Buenos Aires pasando por la cordillera de los Andes. Reedición crítica y estudio preliminar, transcripción y modernización ortográfica, por Carla Ulloa).Cuarto Propio, Santiago de Chile, 2013.

\section{GANPHLAC}

Revista Eletrônica da ANPHLAC, ISSN 1679-1061, No. 17, p. 304-324, jul./dez. 2014. http://revista.anphlac.org.br/ 
DUARTE, Constância Lima. Nísia Floresta: vida e obra. Natal: Editora da UFRN, 1995.

FLORESTA, Nísia. Cintilações de uma alma brasileira. Florianópolis: Editora Mulheres, 1997.

. O Brasil. In: Cintilações de uma alma brasileira. Santa Cruz do Sul: Edunisc; Florianópolis: Editora Mulheres, 1997.

Itinerário de uma viagem à Alemanha. Santa Cruz do Sul: Edunisc: Florianópolis: Ed. Mulheres, 1998 (a).

Três anos na Itália seguidos de uma viagem à Grécia. Vol I. Natal: Editora da UFRN, 1998 (b).

Trois ans en Italie suivis d'un voyage en Grèce. Vol. 2. Paris: E. Dentu: s/d. (c).

FRANCO, Stella Maris Scatena. Peregrinas de outrora: viajantes latino-americanas no século XIX. Florianópolis: Editora Mulheres: São Francisco do Sul: Edunisc, 2008.

FREDERICK, Bonnie. Willy Modesty. Argentine women writers, 1860-1910. Arizona State University, 1998.

LISBOA, Karen Macknow. A Nova Atlântida ou o gabinete naturalista dos doutores Spix e Martius: natureza e civilização na Viagem pelo Brasil. (1817-1820). São Paulo, Dissertação de Mestrado, FFLCH, nov. 1995.

PALLARES-BURKE, Maria Lúcia. A Mary Wollstonecraft que o Brasil conheceu, ou a travessura literária de Nísia Floresta. In: Nísia Floresta, o Carapuceiro e outros ensaios de tradução cultural. São Paulo: Hucitec, 1996.

PRADO, Maria Ligia C. Repensando a História Comparada na América Latina. Revista de História, n. 153, 2º sem. 2005.

PRATT, Mary Louise. Os olhos do império: relatos de viagem e transculturação. Bauru: EDUSC, 1999.

RUSSOTO, Márgara. Punta y pomo del discurso: la voz femenina en la poesía latinoamericana. In: PIZARRO, Ana (org). América Latina: palavra, literatura e cultura. São Paulo: Memorial; Campinas: UNICAMP, 1994.

STUVEN, Ana María. Mujer, família y república. In: AYALA MORA, Enrique (Dir). Historia general de América Latina. Madrid: Trota; Paris, Unesco, 2007.

ULLOA, Carla. Crítica social y gestión cultural de una viajera sudamericana: Maipina de la Barra (1834-1904). Tesis para optar al grado de Magíster en Estudios

\section{GANPHLAC}

Revista Eletrônica da ANPHLAC, ISSN 1679-1061, No. 17, p. 304-324, jul./dez. 2014.

http://revista.anphlac.org.br/ 
Latinoamericanos, Universidad de Chile, 2012, disponible en: http://www.tesis.uchile.cl/handle/2250/110941.

VICUÑA, Manuel. La belle Epoque chilena. Alta sociedad y mujeres de élite. Santiago de Chile: Catalonia, 2010.

\section{GANPHLAC}

Revista Eletrônica da ANPHLAC, ISSN 1679-1061, No. 17, p. 304-324, jul./dez. 2014. http://revista.anphlac.org.br/ 